\title{
Yeşil Pazarlama Faaliyetlerinin Tüketiciler Üzerindeki Etkileri
}

\author{
DOI: 10.26466/opus.615467
}

\section{Dursun Boz * - Cengiz Duran** - Sadık Başköy***}

* Dr, Dumlupınar Üniversitesi, İ̈BF. İşletme / Kütahya / Türkiye
E-Posta: dursunboz@hotmail.com
ORCID: 0000-0003-3206-8950
** Doç.Dr., Dumlupınar Üniversitesi, İ̈BF. İşletme / Kütahya/ Türkiye
E-Posta: cengiz.duran@dpu.edu.tr
ORCID: $\underline{0000-0001-7910-0677}$
*** Bilim Uzmanı, Dumlupınar Üniversitesi, İ̈BF. İşletme / Kütahya/ Türkiye
E-Posta: sadikbaskoy@gmail.com
ORCID:

\section{$\ddot{O} z$}

Küreselleşme, teknolojik ilerleme, nüfus artış hızı ve tüketici beklentileri işletmeler arası rekabetin artmasına neden olmuştur. Bu artış aynı zamanda çevre kirliliğini artırmıştır. Bu artış gün geçtikçe artan çevre sorunların tetiklemiş ve gelecek nesiller için yaşanabilir bir dünya bırakma konusunda endişeler artmıştır. Doğal kaynakların kıt olması nedeniyle zaman içinde tüketiciler, devlet çevresel duyarlılığı yüksek kuruluşlar duyarlılık göstermeye başlamışlardır. Bu duyarlılık tüketicilerin çevre dostu yeşil ürün satın almalarıyla yeşil pazarlama uygulamaları doğmuştur. Yapılan bu çalışmanın amacı tüketicilerin çevre duyarlılı̆̆ı, yeşil pazarlama ve tüketici satın alma kararı arasındaki ilişkinin belirlenmesidir. Bu amaçla Kütahya ili SERA alışveriş merkezinde 210 tüketiciye gönüllülük esasına göre ulaşılmıştır. Elde ettiğimiz bulgularla çevre duyarlılı̆̆ ile tüketici satın alma kararı arasında pozitif yönlü anlamlı ilişkileri tespit edilmiştir. Ayrıca, yeşil pazarlama ile tüketici satın alma kararı arasında pozitif yönlü anlaml ilişkileri tespit edilmiştir. Demografik değişkenlerden cinsiyet ile çevre duyarlılığı, yeşil pazarlama ve tüketici satın alma kararı arasında anlamlı farklılı̆̆a rastlanmamıştır. Demografik değiş̧kenlerden medeni durum ile çevre duyarlılı̆̆ ve tüketici satın alma kararı arasında anlamlı farklılık tespit edilmişken yeşil pazarlama ile arasında anlamlı farklılı̆̆a rastlanmamıştır. Ayrıca tüketicilerin çevre dostu ürünleri satın almak istediklerinde \%21,15 daha fazla ödeme yapacakları tespit edilmiştir.

Anahtar Kelimeler: Yeşil pazarlama, Çevre Duyarlılı̆̆ı, Tüketicinin Satın Alma Kararları 


\title{
The Impact of Green Marketing Activities on Consumers
}

\begin{abstract}
Globalization, technological progress, population growth rate and consumer expectations have led to an increase in competition among enterprises. This increase has also increased environmental pollution. This increase triggered increasingly environmental problems and increased concerns about leaving a habitable world for future generations. Due to the scarcity of natural resources, consumers have started to be sensitive to high levels of public environmental awareness. This sensitivity has aroused green marketing practices with consumers buying eco-friendly green products. The aim of this study is to determine the relationship between environmental sensitivity of consumers, green marketing and consumer purchasing decision. For this purpose 210 consumers were voluntarily reached at the SERA shopping center in Kütahya province. Positive correlation was found between environmental sensitivity and consumer purchasing decision. In addition, positive directional significant relationships between green marketing and consumer purchasing decision were determined. There was no significant difference between gender and environmental awareness among demographic variables, green marketing and consumer purchase decisions. While there was a significant difference between demographic variables and marital status, environmental sensitivity and consumer purchasing decision, no significant difference was found between green marketing. It was also found that consumers would pay $21.15 \%$ more when they wanted to buy eco-friendly products.
\end{abstract}

Keywords: Green Marketing, Environmental Sensitivity, Consumer's Purchase Decisions 


\section{Giriş}

İnsanoğlu var olduğun günden itibaren doğayla ve canlılarla iç içe yaşamıştır. Yaşadığı bu doğaya çoğu zaman hükümran olmaya çalışmıştır. Bu hükümranlığını aklını kullanarak ürettiği araç-gereçlerle yapmaya çalışmıştır. Küreselleşme ve teknolojik gelişmelerle artan sosyalleşme ihtiyacını tüketim ile giderir olmuştur. Bu tüketim talebi üreticiler tarafından karşılanmıştır. Üreticiler bu çılgın talebin karşılanmasında doğal çevreye zararlar vermiş ve doğal kaynaklar azalmıştır. Bu durum bazı tüketicilerin kaygılarını artırdığından dolayı doğaya dost yeşil pazarlama unsurları gündeme gelmiştir. Bu unsurların temelinde, doğanın atalarımızdan miras değil torunlarımıza emanet bırakabileceğimiz bir çevre olduğudur. Bu kaygıyı taşıyan tüketicilerin başlattı̆̆ hareket yeşil pazarlama çatısında bütünleşmiştir.

Yakın zamanlarda çevre ile ilişkin dünya genelinde yaşanan olaylara bakıldığında geçmiş zamanlara kıyasla dengelerin altüst olduğu gözlenmektedir. Çağın son felaketi olarak adlandırılan Küresel Isınma da etkilerini çarpıcı şekilde ortaya koymaktadır. Bu konu medya tarafında sıklıkla dile getirilmekte gerek devletlerin gerekse de işletme tüketicilerin ilgisini çekmektedir. Bilim dünyasında bu durum, sürdürülebilir olmayan gelişme olarak açılamaktadır. Bu durum işletmelerin çevreye ilişkin sosyal sorumluluk projeleri kapsamında değerlendirilmektedir. Bazı işletmeler çevrenin kirlenmesindeki paylarını göz ardı etmeden bu türden projeleri hayata geçirmektedirler. Günümüz işletmeleri faaliyetlerini çevreye duyarlı stratejiler uygulayarak hem sosyal sorumluluk yaklaşımlarını ortaya koymalı hem de yeşil bir dünya özlemi çeken tüketici istek ve beklentilerini karşılayabilmelidir. Araştırmanın yapıldığı yer bu özlemi çeken tüketicilerin sıklıkla uğradıkları alışveriş merkezleridir. Araştırma katılımclarının çoğunluğunun genç tüketiciler olması konunun öneminin anlaşılması açısından önemlidir.

\section{Yeşil Pazarlama}

Günümüz dünyasında hızla değişen ekonomik şartlar pazarlama uygulamalarını önemli kılmaktadır. Pazarlama temel olarak, işletme amaçlarına ulaşmayı sağlamak için ihtiyaçların karşılanması, ürün/hizmet fikirlerinin 
gerçekleştirilmesi, fiyatlandırılması, tutundurulması ve dağıtılmasını kapsamaktadır. Bu kapsam tüketici istek ve beklentilerinin gerçekleştirilmesi için pazarlama yoluyla olmaktadır. Günümüzde pazarlama anlayışı tüketici istek ve beklentilerinin ötesinde bazı sosyal görevleri de içermektedir (Mucuk, 2001, s.5). Bu görevlerin bir kısmı çevreyi korumayı hedeflemiş yeşil pazarlama ile ilgilidir. Yeşil pazarlama faaliyetleri tüm pazarlama faaliyetlerini etkileyerek yeşil üretim, yeşil satış, pazar araştırmaları, pazarlama kararları, teknolojileri, ambalaj, etiketlenme, tüketim ve atılmasını kapsamaktadır (Uydacı, 2011, s.40). Bu kapsamda ürünlerin kullanılması sonucunda dönüşleri ya üretildikleri yer ya da doğaya olmaktadır. Günümüz tüketici tercihlerinde geri dönüşümlü ürünler önem kazanmaktadır. Bu önem yeşil pazarlamayı sosyal pazarlama, sosyal sorumluluk ve sürdürülebilirlik ile aynı çatıda birleştirmektedir. Yeşil pazarlama ile hem üretim hem de tüketim yapıldığında kıt olan doğal kaynakların korunmasını sağlamak ve doğa dostu ürünleri teşvik etmektir (Uydacı, 1999, s.84).

Son zamanlarda tüketicilerin çevreye daha duyarlı hale gelmeleri ve çevreye önem veren işletmelere olumlu bakış açıları işletme yöneticilerini etkilemektedir. Tüketiciler sadece işletmenin etik anlayışını, kültürünü, vizyonunu, misyonunu belirlemekle kalmıyor ayn zamanda çevresel duyarlılıklarını, kurumsal itibarını ve imajını belirliyor. Bu bağlamda doğal çevrenin korunması günümüz işletmelerinde üretimden yönetime, insan kaynaklarından pazarlamaya kadar daha fazla alanda etkileyecektir (Koçarslan, 2015, s.84). Modern pazarlamada tüketicilerin genelde çevresel duyarlılıkları ve bilinçlerinin yüksek olduğu bilinmektedir. Bu sebepten dolayı çoğu işletme yeşil pazarlama faaliyetlerini rakiplerinin önüne geçecek bir rekabet avantajı yakalamak için önem vermiştir. Yeşil pazarlama bu bağlamda modern iş dünyasının başlıca eğilimi olarak değerlendirilebilir (Ku vd., 2012, s.41).

Peattie (2001) çalışmasında yeşil pazarlamayı 3 safhada inceler, bu safhalar; 1960-1980 arası Ekolojik Pazarlama, 1980-2000 arası: Çevreci Pazarlama, 2000 sonrası: Sürdürülebilir Pazarlamadır (Peattie, 2001, s.129).

Ekolojik Pazarlama: Ekolojik pazarlama çevreye ve insanlığa zararlı olduğu bilinen bazı ürünler için bağımlılığı düşürmeyi amaçlayan, çevreye dost ürün ve hizmetler ile ilgili pazarlama faaliyetleri olarak tanımlanmaktır (Ceritoğlu, 2011, s.72). Ekolojik pazarlamayla alakalı alan- 
yazına bakıldığında bu pazarlama türündeki hedefin tarım, sanayi, petrol ve otomotiv sektörlerinde kullanılan sentetik kimyasalların oluşturduğu hava kirliliği, atık sorunları, fosil yakıtların azalması gibi çevreyle alakalı problemleri içerdiği görülebilir (Sert, 2017, s.36).

Çevreci Pazarlama: Yeşil pazarlamanın ikinci safhası olan çevreci pazarlama 1980 sonlarında ortaya çıkmıştır. Bu dönemde yaşanan Bhopal felaketi (1984), Çernobil faciası (1986), Exxon-Valdez (1989) felaketleri medyada geniş yankı bulmuştur. Medyada geniş yankı bulan bu gelişmeler çevresel kaygıları artırarak kitlesel çevreci eylemlere dönüşmüştür. Çevreci gruplar tarafından organize edilen kitlesel duyarlı tüketici eylemleri tüketici davranışlarının değişmesinde etken rol oynamıştır (Aslan, 2007, s.21). Teknolojik gelişmeler ile haberleşme teknolojisindeki ilerlemeler medyanın çevre ile ilgili olayların ve iletişimin gelişmesiyle ve medya olgusunun da çevreyle ilgili olayları gündemde tutmasıyla toplumda çevresel endişeleri tetikleyerek kitlesel boyutlarda önem kazanmaya başlamıştır (Sert, 2017, s.36).

Sürdürülebilir Pazarlama: Ekonomiyle alakalı alanyazında toplumsal refaha ulaşmada sürekli büyüme anlatılmaktadır. İşletmeler de sürekli büyümeden kendine düşen payı almaktadır. Sanayi devrimi ile sürekli büyümenin limitsiz refah artışının temelini oluşturacak ekonomik modellemeler benimsenmiştir. Bu modellemelerin ivmelediği çabalarla sahip olduğumuz doğal kaynaklar tükenmekte ve çevresel atıklar ortaya çımaktadır. Bu atıklar birçok ekolojik sorunun da oluşmasını sağlamıştır (Karalar ve Kiracı, 2011, s.63). Sürdürülebilirlik ilkesinin pazarlama uyarlaması olarak karşımıza çıkan sürdürülebilir pazarlama işletmelerin sadece temiz ve yararlı teknoloji kullanımıyla çevresel duyarlılı̆̆ıyla gelecek kuşakları kapsayan uygulamalardır. Aynı anda sadece pazarlamanın bir öğesi olarak bakılmayan diğer işletme unsurlarını da kapsayacak şekilde işletme faaliyetlerin gerçekleştirilmesini içermektedir (Koçarslan, 2015, s.94).

Doğal kaynakların içindeki çevre ekonomik ilerlemeyi, canlıların yaşamsal ihtiyaçlarını direkt etkileyen önemli bir estetik unsurdur. Çevrenin sunmuş olduğu imkanlar sayesinde üretim ve tüketimde insanlar tarafından kullanılagelmiştir. Doğada hammadde olarak var olan kaynaklar üretim 
süreçlerinden geçirilerek ürün/hizmete dönüşerek tüketicinin kullanımına sunulmaktadır. Üretim süreçlerinde ister istemez doğal çevre kirlenmekte ve bu kirlilik çoğu zaman önlenememektedir (Arslanoğlu, 2019, s.3; Karaca, 2012, s.140). Haberleşme teknolojisindeki gelişmeler ile eğitimi seviyesinin yükselmesi sonucunda toplumlar çevre konusuna daha duyarlı ve bilinçli hareket etmeye başladılar. Bu hareket işletmeleri de yakından ilgilendirmektedir. Kıt kaynakların verimli kullanılması yaşadığımız doğal çevreye en az zararlı ürün ve hizmet üretimi konusunda işletmeler de hassas davranmaya başladılar. Bu davranışın temelinde tüketicilerin doğa dostu ürün ve hizmetlere önem vermesi de desteklemektedir. İşletmeler hem toplumun hem de doğa dostu tüketicilerin bu beklentilerini önemsemek zorunda kalmışlardır (Koçarslan, 2015, s.98).

\section{Tüketici Kararları}

Tüketici, "bireysel arzu, istek ile gereksinimlerini gerçekleştirmek için pazarlama bileşenleri satın alan veya satın alma gücü bulunan gerçek bireydir. Tüketici, bir kurumun pazarlama bileşenlerinin kabulünde veya reddindeki kişiler olduğundan ve bunların bütünü işletmelerin hedef pazarı olduğu için, işletmelerin pazara yönelik uygulamalarında temel belirleyici olurlar (İslamoğlu, 2003, s.5). Tüketim sürecinin içinde yer alan her birey tüketici olarak isimlendirilir. Tüketiciler, özünde kişisel ihtiyaçlarını, ailevi ihtiyaçlarını çözmek için satın alan bireylerdir (Jisana, 2014, s.34). Pazarlama bağlaminda "tüketici kimdir?" sorusunun yanitı arandığında araştırmaların daha ziyade tüketicinin maddi ihtiyaçlarıyla alakalı olduğu görülmektedir. Ancak günümüzde tüketicinin duygu ve düşüncesel gereksinimleriyle de ilgilenilmesi gereği doğmuştur. Bu gereklilik maddi tüketim unsurlarının haricinde maddi olmayan kültür, eğlence gibi tüketim unsurlarının da görülmesini gerekli kılmıştır (Altunışık, Özdemir, Torlak, 2006, s.59).

Tüketici davranışı kısaca; "bireylerin mal ve hizmetleri tüketirken üstlenmiş olduğu faaliyetler" şeklinde tanımlanabilir (Blythe, 2013, s.3). Bir diğer tanımda tüketici davranışı, kişilerin zaman ve gelir gibi tüketimle alakalı kaynakları nasıl kullanacaklarına ilişkin verdikleri kararlardır. İktisadi anlamda, ürün ve hizmet tüketimiyle sağlanan dolaylı tatmin, fayda olarak isimlendirilmektedir. Tüketicinin bu doyumu sabit geliriyle 
mümkün olan en iyi faydayı sağlayacağı varsayılır. Tüketici davranışlarının anlaşılmasında ekonomi bilimi başta olmak üzere sosyoloji, psikoloji ve pazarlamayı da içeren birçok disiplinden elde edilecek bilgiler kullanılır (Glowa, 2001, s.4). Bu bilgilerle çevre konusunun pazarlama yazınına girmesiyle beraber pazarlama alanında "yeşil" ile başlayan alt kavramların türetildiği görülmektedir. Bu kavramlardan birisi de "yeşil tüketici"dir. Yeşil tüketiciler, satın alma davranışlarıyla çevreyi etkileyen tüketicilerdir. Yeşil tüketicilerin sosyal sorumluluk içeren tüketim kararlarıyla satın aldıkları ürünün üreticilerini, üretim faaliyetlerini ve uygulamalarını, kullanılan hammaddeleri, ürünlerin kullanım sırasında ve atıldıktan sonra çevredeki etkilerine dair bilgilerin araştırmasını içerir (Karaca, 2013). Bu içerikle tüketiciler, satın alma kararlarını alırken kişisel, psikolojik, ekonomik ve sosyo-kültürel unsurlardan etkilenerek bu davranışlarda bulunurlar.

Yaş ve Kuşak: Pazarlamacılar, pazarı bölümlere ayırmada genellikle yaş gruplarını kullanırlar. Pazarın yaş grupları baz alınarak sınıflandırılması aynı jenerasyonda olan kişilerin benzer tüketim kalıpları ve satın alma davranışları olmasındandır (Schewe-Meredith, 2004, s.52). Kişilerin yaşam süreleri belirli dönemlere (çocukluk, gençlik, olgunluk ve yaşlılık) ayrılır. Bireyler bir dönemden diğerine geçtiğinde farklılaşan ürün ve hizmetler satın alma eğilimindedirler (Kotler vd. 2005).

Cinsiyet: Satın alma kararını etkileyen unsurlardan biri de cinsiyettir. Erkekler ve bayanlar arasındaki farklılıklar, tüketici davranışlarının cinsiyete göre seçilecek ürünlerin farklı olabileceğini ve satışı yapılacak ürün tanıtımının da buna göre şekilleneceğidir. Çalışan kadın sayısındaki artış mutfak ve ev işlerini hızlandırmakta; ev hanımlara kolay çözümler sunarak seçeneklerinin artışına sebep olmaktadır (Toygar, 2014, s.52).

Kişilik: Bireyler çeşitli kişilik özelliklerine göre sınıflandırılmış bu noktadan hareketle bireyin satın alma davranışı araştırılmıştır. Yapılan çalışmalarda kişilik ile satın alma davranışı arasında zayıf ilişki bulunmuş ancak, tüketici davranışlarının anlaşılmasında kolaylaştırıcı rol oynadığını kabul edilmiştir (Tüylü, 1995, s.34). 
Algılama: Psikolojik unsurlardan biri olan algılama, kişinin duyu organlarından gelen uyarıcıları duyumsadıktan sonra oluşanlar içerisinden tüm bilişsel deneyimleri etkisiyle uyarıları seçebilmesi, belirli şekilde sıralayarak anlamlarını yorumlamadır. Algılama geçmiş deneyimlerden, motivasyondan, inançlardan, tutumlardan ve öğrenme yeteneğinin etkileriyle bağlantılıdır (Smith, 1994, s.78).

Öğrenme: Yaşadıklarımız sonucu kazandığımız öğretiler ve öğrenme aşamasında edinilen tecrübeler önemli ölçüde insan davranış ve arzularını yönlendirir. Bu öğrenmelerimizin arasına tüketim öğrenimini de sayabiliriz. Böyle bir durum olmasa idi her yeni satın alma davranışında daha önceki deneyimler bize engel olarak çıkacak ve dolayısıyla daha fazla çaba sarf etmemize sebep olacaktı (Kocabaş ve Elden, 2001).

İnanç ve Tutumlar: Birey yaptığı eylemi ve yaşantısı sonucu sahip olduğu öğrenimlerinden inanç ve tutumlarını oluşturmaktadır. Bireyde oluşan bu inanç ve tutumlar tüketici davranışını ve tutumlarını etkiler. İnanç, bireyin dış dünyayı araştırmasında ve sonucunda elde ettiği tecrübelerden çıkarım yaptığı bilgilerdir (Djaadi, 2016, s.72). Kişinin bir şey hakkında tamamlayıcı düşünceleri inançlarından dolayı kaynaklanır (Başaran, 1991, s.297).

Ekonomik yapı ve Doğa: Ekonomik yapı, gelecekteki beklentiler ve ekonomik canlılık çeşitli biçimlerde ve büyüklükte tüketicilerin satın alma davranışlarının belirleyicisidirler. Çevre dostu yani yeşil ekonomi çevre risklerini ve çevreye zarar vermeden sürdürülebilir büyümeyi amaçlayan ekonomi şeklinde tanımlanabilir. İnsanın yaşadığı çevrede herhangi bir karşıllk beklemeksizin, insanoğluna hizmet etmektedir. Çevresel sorunları çözmek amacıyla insan-doğa-çevre ilişkisinde bazı temel ilkeler kabul edilmelidir (Uydac1, 2011, s.26-27).

Gelir Düzeyi: Bireyin satın alma davranışını değiştiren önemli unsurlardan biri de gelir düzeyidir. Bireyin gelirinden yasal vergiler düşüldükten sonra geriye kalan kısma gelir denilir. Bireyin geliri arttıkça harcamaları da ona paralel şekilde artış göstermektedir. İşletmeler ve tüketiciler için talepler ne kadar net ise, karmaşa da o derece azdır. Tü- 
ketici tepkileri farklı biçimlerde kendini gösterebilir. Bu biçimler; satın alma davranışındaki değişiklik, organizasyonun çevreci tutarsızlığını protesto etmek, tüm ürünlerini boykot etmek gibi kendini gösterebilir (Akdeniz Ar, 2011, s.100-101).

Aile: Bireyin satın alma davranışlarında ailesinden etkilendiğinden dolayı pazarlama ve tüketici davranışı bağlamında aile önemli bir rol arz etmektedir. Aile, sosyal yapıdaki en farklı toplumsal birim olduğu için satın alma davranışında da önemli role sahiptir. Aile; bireyin güdüleri, tutumları ve benliklerini etkiler. Hem kazanan hem de harcayan yapısıla aile toplumsal yapıda farklı bir yere sahiptir (Bilge ve Göksu, 2010, s.138).

Kültür: Tüketici davranışlarını etkileyen bir diğer unsur olan kültür insan yaşantısını ve tüketim tarzlarını etkiler. Kültür, insanların benzer hadiselere birbirine benzeyen tepkiler vermesine sebep olan, çevre tarafından öğretilen ve yaşantıyı etkileyen unsurlardan biridir. Bir kültürde olumlu olan bir olgu başka bir kültürde olumsuz olabilir. Tüketicinin satın alma davranışında kültürel olgular önemli yer tutmaktadır (Toygar, 2014, s.55).

Statü: Tüketicinin satın alma davranışlarını etkileyen diğer bir unsur da statüdür. Tüketici davranışlarını anlamak için tüketicinin toplum içindeki hangi sosyal sınıfa mensup olduğu veya kendisine atfedilen statünün ne olduğunun bilinmesi önemlidir. Kişiler içinde bulunduğu gruba uymak, onlara benzemek için bazı ürün /hizmetleri tüketim eğilimi taşırlar. Bu eğilim toplum tarafından bazı değişkenlere göre belirlenen statü derecelerinin gerekliliklerini yerine getirmede bazı tüketim kalıplarının benimsenmesiyle olmaktadır (Wood ve Hayes, 2012, s.325).

Yaşam Tarzı: Tüketicinin satın alma davranışlarını etkileyen diğer bir unsur da yaşam tarzıdır. Yaşam tarzı, kişinin zamanını nasıl geçirdiği, aktiviteleri, ilgi alanları, tüketim ile alakalı faaliyetleri, alışkanlıkları ve görüşleridir. Tüketicinin satın alma davranışları yaşam tarzı ile alakalı bilgiler sunar. Kısaca, yaşam tarzı, tüketicinin niçin satın alma yaptığının cevabını verir. Bu yüzden tüketicinin satın alma davranışlarını etkileyen 
önemli bir unsurdur. Tüketicinin geçmiş tecrübeleri, içinde yaşadığ1 kültür, demografik özellikleri, ekonomik şartlar ve değerleri de yaşantısını etkiler. Bu unsurların etkisi nedeniyle yaşam biçiminin oluşumunda, satın almada ve tüketimde etkilidir (Hamşığlu, 2013, s.20).

Pazarlamacıların sorumluluğu ürün/hizmetler ile alakalı bilgi verici tanitım faaliyetlerinde bulunmaktır. Bu faaliyetleri satın alma sürecinin safhaları olarak şu başlıklarla özetleyebiliriz (Mucuk, 2001, s.89); İhtiyacın ortaya çıkışı, Alternatiflerin belirlenmesi, Çözüm seçeneklerinin belirlenmesi, Satın alma, Satın alma sonrasındaki davranışlardır.

\section{Veri, Yöntem ve Hipotezler}

$\mathrm{Bu}$ araştırmanın amacı çevre duyarlılı̆̆ 1 ve yeşil pazarlama faaliyetlerinin tüketici kararları üzerindeki etkileşiminin belirlenmesidir. Bu amaçla Kütahya ilinde SERA alışveriş merkezindeki 210 gönüllü tüketiciye ulaşılmıştır. Araştırmada Yeşil Pazarlama ölçeği ile demografik değişkenleri içeren veriler kullanılmıştır. Yeşil pazarlama ölçeği 34 ifadeden ve 3 alt faktörden oluşmaktadır. Yeşil pazarlama faaliyetleri alt faktörü 16 ifadeden, Çevre Duyarlılığı alt faktörü 4 ifadeden, Satın alma kararları 14 ifadeden oluşmaktadır. Toplam 32 ifade Likert tipinde (1.Hiç Katılmıyorum,- 5.Tamamen Katılıyorum) ve 6 adet demografik bilgiler içeren ifadeler ile 2 adet çevresel farkındalık ifadelerinden oluşan anket 210 tüketiciye uygulanmıştır. Araştırmada kullanılan ölçek Necla Kuduz (2011) yüksek lisans tezi ve Yeşil Pazarlama (2013) isimli kitabından alınmıştır. Araştırma verilerinin analizi için SPSS (20.0) paket programı kullanılmıştır. Araştırmaya ait kavramsal modeli şekilde sunulmuştur.

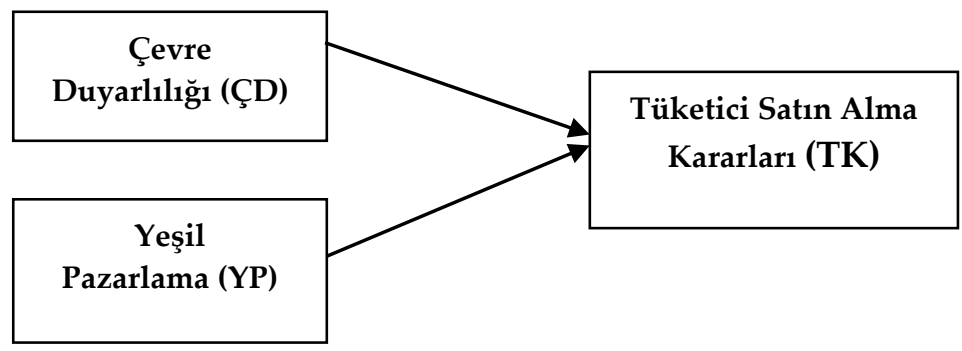

Şekil 1. Araştırma Modeli 
Araştırmaya ait hipotezler şunlardır;

- H1: Çevre Duyarlılı̆̆ı, Tüketicinin Satın Alma kararları üzerinde anlamlı etkisi vardır

- H2: Yeşil Pazarlama, Tüketicinin Satın Alma kararları üzerinde anlamlı etkisi vardır

\section{Bulgular}

Bu kısımda araştırma kapsamındaki SERA alışveriş merkezinde 210 tüketiciyle oluşturulan veriler ile demografik özellikler, kullanılan ölçeklerin güvenilirlik analizi, frekans dağılımı, fark testleri, korelasyon, regresyon analizleri vb. ile yorumlanması bulunmaktadır.

Tablo 1. Demografik Özellikler

\begin{tabular}{|c|c|c|c|c|c|}
\hline Cinsiyet & Frekans & $\%$ & Medeni Durum & Frekans & $\%$ \\
\hline Kadın & 117 & 55,7 & Evli & 126 & 60,0 \\
\hline Erkek & 93 & 44,3 & Bekâr & 84 & 40,0 \\
\hline Yaş & Frekans & $\%$ & Gelir TL. & Frekans & $\%$ \\
\hline 18'denküçük & 17 & 8,1 & $0-1000$ & 34 & 16,2 \\
\hline $19-29$ & 118 & 56,2 & $1001-2000$ & 60 & 28,6 \\
\hline $30-39$ & 35 & 16,7 & 2001 ve üstü & 116 & 55,2 \\
\hline $40-49$ & 22 & 10,5 & Meslek & Frekans & $\%$ \\
\hline $50-59$ & 14 & 6,7 & $\begin{array}{c}\text { Profesyonel } \\
\text { (Dr.,Avukat,Müh. vb.) }\end{array}$ & 21 & 10,0 \\
\hline 60 ve ustu & 4 & 1,9 & $\begin{array}{l}\text { İsletme sahibi } \\
\text { Esnaf }\end{array}$ & $\begin{array}{c}3 \\
11\end{array}$ & $\begin{array}{l}1,4 \\
5,2\end{array}$ \\
\hline Eğitim & Frekans & $\%$ & Memur & 10 & 4,8 \\
\hline İlköğretim & 28 & 13,3 & Isc1 & 15 & 7,1 \\
\hline Lise & 47 & 22,4 & EvHanımı & 31 & 14,8 \\
\hline Ön Lisans & 22 & 10,5 & Emekli & 17 & 8,1 \\
\hline Lisans & 106 & 50,5 & İssiz & 11 & 5,2 \\
\hline Lisansüstü & 7 & 3,3 & Öğrenci/Diger & 91 & 43,3 \\
\hline
\end{tabular}

Tabloya göre çalışmaya katılanların çoğunluğu kadın (\%55,7), evli $(\% 60,0)$, yaş aralığı 19-29 (56,2), aylık geliri 2001 TL. ve üstü $(\% 55,2)$, eğitim düzeyi lisans $(\% 50,5)$, meslekleri öğrenci/diğer $(\% 43,3)$ olduğu görülmektedir. 


\section{Ölçeklerin Geçerlilik ve Güvenilirlik Analizi}

Araştırma verilerinin faktör analizine uygunluğunun testi için KaiserMeyer-Olkin (KMO) örneklem yeterliliği testi ve Bartlett Küresellik testi yapılmıştır. KMO örneklem yeterliliği testinde uygun olan alt sınır değeri 0,50'dir. Bu değerin 0,60-0,80 arası yeterli iken 0,80 - 0,90 arasında olması çok iyi olarak değerlendirilmektedir (Kalaycı, 2010:322). Ortak varyansın açılanmasında 200 üstü örneklemlerde 0,50'den büyük olması beklenmelidir (Field 2007). Faktörlerin korelasyona bağlı iç tutarlıkları için Cronbach's Alpha katsayısının 0,80'den yüksek olması iyi olarak değerlendirilebilir (Büyüköztürk, 2007).

Tablo 2. KMO ve Bartlett's Testi

\begin{tabular}{|c|c|c|}
\hline \multicolumn{2}{|c|}{ Kaiser-Meyer-Olkin Measure of Sampling Adequacy. } & ,676 \\
\hline \multirow[t]{3}{*}{ Bartlett's Test of Sphericity } & Approx. Chi-Square & 4553,742 \\
\hline & $\mathrm{df}$ & 496 \\
\hline & Sig. & ,000 \\
\hline
\end{tabular}

Tabloya göre ölçeğin KMO değeri ,676 ile yeterli olduğu belirlenmiştir.

Tablo 3. Güvenilirlik analizi

$\begin{array}{cc}\text { Cronbach's Alpha } & \mathrm{n} \\ , 830 & 32\end{array}$

Tabloya göre Güvenilirlik katsayısı Cronbach's Alpha Değeri ,830 sonucu ile çok iyi olduğu belirlenmiştir.

\section{Demografik Özellikler ile değişkenlere ait T-Testleri ve Anova Testleri}

Demografik özellikler ile çevre duyarlılığı (ÇD), yeşil pazarlama (YP) ve tüketici satın alma kararları (TK) arasındaki ilişkiler t-testi ve Anova ile analiz edilmiştir. T-Testi iki örneklem arasında bulunan ortalamaların önemli seviyede farklılık olup/olmadığının ayrımında kullanılmasıdır (Kalayc1, 2010, s.74). Tek yönlü varyans (ANOVA) analizi ise ikiden fazla örneklem grubu arasındaki ortalamalar arasında farklılık olup/olmadığının ayrımının belirlenmesidir (Kalaycı, 2010, s.131). 
Tablo 4. Medeni Durum T-Testi

\begin{tabular}{lrccccc}
\hline & & $\mathrm{N}$ & Ort. & S.H. & $\mathrm{t}$ & $\mathrm{P}$ \\
\hline ÇD & Evli & 126 & 4,0136 &, 41441 & $-3,094$ &, 002 \\
\cline { 2 - 7 } & Bekar & 84 & 4,1879 &, 37728 & $-3,153$ &, 002 \\
\hline TK & Evli & 126 & 3,4348 &, 60596 & $-4,321$ &, 000 \\
\cline { 2 - 7 } & Bekar & 84 & 3,7959 &, 57359 & $-4,369$ &, 000 \\
\hline
\end{tabular}

Tabloya göre $\mathrm{p}<0,05$ anlamlllık düzeyinde ÇD ve TSAK konusunda bekar olanların evli olanlara göre istatistiksel olarak anlamlı farklılık vardır. Bu farklılık bekar tüketicilerin daha çevreci algılara sahip olmalarıyla açıklanabilir.

Tablo 5. Yaş ile ÇD ve TK arasında çoklu karşılaştırma testi (Post Hoc.Tukey)

\begin{tabular}{|c|c|c|c|c|c|c|c|}
\hline \multirow[t]{2}{*}{ Değişken } & \multirow{2}{*}{$\begin{array}{l}\text { (I) } \\
\text { Yasınız }\end{array}$} & \multirow[t]{2}{*}{ (J) Yasınız } & \multirow[b]{2}{*}{ Ort.Fark.(I-J) } & \multirow[b]{2}{*}{ S.H. } & \multirow[b]{2}{*}{$\mathbf{P}$} & \multicolumn{2}{|c|}{ 95\% Güven } \\
\hline & & & & & & Altsınır & Üstsınır \\
\hline ÇD & $19-29$ & 18'den kucuk &,- 05053 & , 10126 & ,996 &,- 3419 & ,2408 \\
\hline \multirow{5}{*}{ TK } & & $30-39$ &,$- 30659^{*}$ & 07513 & 001 &,- 5227 &,- 0904 \\
\hline & & $40-49$ &,$- 31466^{*}$ & ,09065 & ,008 &,- 5755 &,- 0539 \\
\hline & $19-29$ & 18'den kucuk & ,09019 & ,15323 & ,992 &,- 3506 &, 5310 \\
\hline & & $30-39$ &,$- 35879^{*}$ & ,11369 & ,022 &,- 6859 &,- 0317 \\
\hline & & $40-49$ &,$- 51046^{*}$ & 13717 & 003 &,- 9051 &,- 1158 \\
\hline
\end{tabular}

Post Hoc Tukey Testi çoklu karşılaştırmalara imkanı veren (Kalaycı, 2010) bir testtir. ÇD ve TK konusunda 19-29 yaş aralığında çalışanların 30-39 ve 40-49 yaş aralığında çalışanlara göre $\mathrm{p}<0,05$ anlamlılık düzeyinde negatif yönlü anlamlı farklılık görülmektedir. Bu farklılı̆̆ın söz konusu yaş grubu tüketicilerin çevre duyarlılığı ve satın alma kararları algılarının netleşmemesiyle açılanabilir.

Tablo 6. Eğitim ile YP ve TK arasında çoklu karşılaştırma testi (Post Hoc.Tukey)

\begin{tabular}{|c|c|c|c|c|c|c|c|}
\hline \multirow[t]{2}{*}{ Değişken } & \multirow[t]{2}{*}{ (I) Egitim } & \multirow[t]{2}{*}{ (J) Egitim } & \multirow[b]{2}{*}{ Ort.Fark. (I-J) } & \multirow[b]{2}{*}{ S.H. } & \multirow[b]{2}{*}{$\mathbf{P}$} & \multicolumn{2}{|c|}{ 95\% Güven } \\
\hline & & & & & & Altsinir & Üstsınır \\
\hline \multirow[t]{4}{*}{$\mathrm{YP}$} & \multirow[t]{4}{*}{ İlkogretim } & Lise & ,14623 & 06995 & ,228 & $\begin{array}{l}-0463 \\
\end{array}$ & ,3388 \\
\hline & & Onlisans & , 10390 & , 08348 & ,725 & -1259 & ,3337 \\
\hline & & Lisans & , $17460^{*}$ & ,06226 & ,043 & , 0032 & ,3460 \\
\hline & & Lisansüstü & 30159 & ,12382 & ,110 & $\begin{array}{ll}-0392 \\
\end{array}$ & ,6424 \\
\hline \multirow[t]{4}{*}{ TK } & \multirow[t]{4}{*}{ İlkogretim } & Lise & ,11686 & ,14389 & ,927 &,- 2792 &, 5129 \\
\hline & & Onlisans & ,20431 & ,17172 & ,757 &,- 2683 & 6769 \\
\hline & & Lisans & ,36653* & ,12807 & ,037 & 0141 & ,7190 \\
\hline & & Lisansüstü & 67092 & ,25470 & ,068 &,- 0301 & 1,3719 \\
\hline
\end{tabular}


YP ve TK konusunda ilköğretim mezunu tüketicilerin Lisans mezunu tüketicilere göre $p<0,05$ anlamlılık düzeyinde pozitif yönlü anlamlı farklılık görülmektedir. Bu farklılık iyi eğitimli tüketicilerin yeşil pazarlama ve satın alma kararlarında rasyonel davrandıkları ile açıklanabilir.

Tablo 7. Daha Fazla Ödeme Ortalaması

\begin{tabular}{lrr}
\hline$N$ & Değer & 210 \\
& Eksik & 0 \\
Ortalama & & 21,1548 \\
\hline
\end{tabular}

Tabloya göre dostu ürünlere diğer ürünlerden ne kadar fazla ödeme yapabileceğinin ortalaması alınmış $(\bar{X}=21,1548)$ olup tüketicilerin çevre dostu ürünlere \%21,15 daha fazla ödeme yapacakları tespit edilmiştir.

Tablo 8. Geri Dönüşüm Simgeleri Bilinirliği

\begin{tabular}{|c|c|c|c|c|c|}
\hline \multicolumn{6}{|c|}{ 1.Simge (Geri dönüşüm veya Geri Kazanım) } \\
\hline & & Frekans & $\%$ & Geçerli \% & Küm. $\%$ \\
\hline & Evet & 126 & 60,0 & 60,0 & 60,0 \\
\hline & Hayır & 84 & 40,0 & 40,0 & 100,0 \\
\hline & Toplam & 210 & 100,0 & 100,0 & \\
\hline \multicolumn{6}{|c|}{ 2.Simge (Geri dönüşüm veya Geri Kazanım) } \\
\hline & & Frekans & $\%$ & Geçerli \% & Küm. \% \\
\hline & Evet & 144 & 68,6 & 68,6 & 68,6 \\
\hline & Hayır & 66 & 31,4 & 31,4 & 100,0 \\
\hline & Toplam & 210 & 100,0 & 100,0 & \\
\hline \multicolumn{6}{|c|}{ 3.Simge (ÇEVKO vakfı üyesi) } \\
\hline & & Frekans & $\%$ & Geçerli \% & Küm. \% \\
\hline \multirow{3}{*}{$\begin{array}{c}\text { CENKO } \\
\text { GA }\end{array}$} & Evet & 124 & 59,0 & 59,0 & 59,0 \\
\hline & Hayır & 86 & 41,0 & 41,0 & 100,0 \\
\hline & Toplam & 210 & 100,0 & 100,0 & \\
\hline \multicolumn{6}{|c|}{ 4.Simge (Geri dönüştürülmüş malzemeden üretilmiş ürün) } \\
\hline & & Frekans & $\%$ & Geçerli \% & Küm. \% \\
\hline & Evet & 51 & 24,3 & 24,3 & 24,3 \\
\hline & Hayır & 159 & 75,7 & 75,7 & 100,0 \\
\hline & Toplam & 210 & 100,0 & 100,0 & \\
\hline \multicolumn{6}{|c|}{ 5.Simge (Yeşil nokta-Ekolojik uygunluk) } \\
\hline & & Frekans & $\%$ & Geçerli \% & Küm. \% \\
\hline & Evet & 91 & 43,3 & 43,3 & 43,3 \\
\hline & Hayır & 119 & 56,7 & 56,7 & 100,0 \\
\hline & Toplam & 210 & 100,0 & 100,0 & \\
\hline
\end{tabular}


Araştırmaya katılan tüketicilerin çoğunluğunun 1 , 2 ve 3 . simgeleri bildikleri ancak 4 . ve 5. simgeleri bilemedikleri tespit edilmiştir. Bundan dolayı yeşil pazarlamayla ilgili işletmelerin kamu spotu niteliğindeki bilgilendirici afişler yaptırması önerilebilir.

\section{Değişkenler arası Korelasyon Analizleri}

İki ya da daha çok değişken arasında bulunan ilişkinin büyüklük, düzeyi ve yönünün tespit edilmesinde kullanılan istatistiki metoda korelasyon denir. Nedensellik ile korelasyon birbirlerine yakın kavramlar olarak görülse de farklı kavramlar olup araştırmaya nedenselliğin sebebini bulmakta önbilgi verir (Gürbüz ve Şahin, 2014). Korelasyon analizinde ilişkinin varlığı korelasyon katsayısıyla bulunabilir. " $\mathrm{r}$ " ile gösterilen korelasyon katsayısı -1 ile +1 arasında değerler almaktadır (Nakip, 2006, s.342-343). Açıklayıcı Faktör analizi ile belirlenen değişkenler arasındaki ilişkilerin bulunmasında "Pearson Korelasyon Analizi" kullanılmaktadır. Bu analizde $r=$ "0,00-0,20 Çok Zayıf”, "0,20-0,40 Zayıf”, “0,40-0,60 Orta”, “0,60-0,80 Yüksek”, “0,80-1,00 Çok Yüksek" ilişki olduğu değerlendirilir (Akgül ve Çevik, 2005, s.359).

Tablo 9. ÇD, YP ve TK arasında Korelasyon analizi

\begin{tabular}{llccc}
\hline & Korelasyon & ÇD Duyarlılı̆̆ & YP Pazarlama & TK alma \\
\hline ÇD & Pearson C. & 1 &, $247^{* *}$ &, $441^{* *}$ \\
& Sig. (2) & &, 000 &, 000 \\
& N & 210 & 210 & 210 \\
\hline YP & Pearson C. &, $247^{* *}$ & 1 &, $219^{* *}$ \\
& Sig. (2) &, 000 & &, 001 \\
& N & 210 & 210 & 210 \\
\hline TK & Pearson C. &, $441^{* *}$ &, $219^{* *}$ & 1 \\
& Sig. (2) &, 000 &, 001 & 210 \\
& N & 210 & 210 & \\
& & & &
\end{tabular}

Tabloda görüldüğü üzere ÇD ile YP arasında $(r=0,247)$ kuvvetinde $p<0,005$ anlamlılık düzeyinde pozitif yönlü zayıf düzeyde bir ilişki vardır. Ayrıca YP ile TK arasında $(r=0,219)$ kuvvetinde zayıf düzeyde ilişki, ÇD ile TK arasında $(r=0,441)$ kuvvetinde pozitif yönde orta düzeyde bir ilişki görülmektedir. 


\section{Değişkenler arası Regresyon Analizi}

Regresyon analizinin yapılmasının gayesi; değişkenler arasındaki etkinin test edilmesi, iki değişkenden birinin değişiminin diğerindeki değişimi açıklanmasında kullanılan istatistiksel yöntemdir. Bu yöntem genellikle değişkenler arasındaki neden-sonuç ilişkisinin test edilebilmesinde kullanılmaktadır. Birden çok bağımsız değişken ile geçerli ve açıklayıcı modeller üretilebildiğinden dolayı sıklıkla kullanılan istatistiksel yöntemlerden biridir (Çağlayan ve Güriş, 2005: 199). Regresyon analizinde

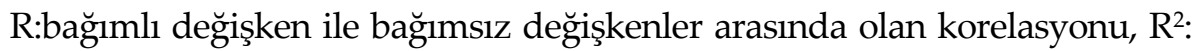
bağımlı değişkendeki değişimin bağımsız değişken tarafından ne kadarına kadar açıkladığı, F: yapılan regresyon analizinin anlamlı olup/olmadığını $(\mathrm{p}<0,05$ den küçük olması), $\beta$ : bağımsız değişkenin etkisinin sabit tutularak bağımlı değişken üzerindeki etkisinin testinde kullanılmaktadır (Kalaycı, 2010, s.259-269). Araştırmanın bu kısmında ÇD, YP ve TK arasındaki regresyon analizleri sunulmuştur.

\section{Tablo 10. Regresyon analizi}

\begin{tabular}{|c|c|c|c|c|c|}
\hline ÇD ve TK & $\mathbf{R}$ & $\mathbf{R}^{2}$ & Tah.S.H. & $F$ & $\mathbf{P}$ \\
\hline \multirow{3}{*}{ Sabit } & 0,441 & 0,195 & 0,36709 & 50,329 & 0,000 \\
\hline & $\beta$ & S.H. & Beta & $t$ & $\mathbf{P}$ \\
\hline & 3,040 & 0,149 & & 20,364 & 0,000 \\
\hline \multirow[t]{2}{*}{ ÇD } & ,292 & 0,041 & 0,441 & 7,094 & 0,000 \\
\hline & \multicolumn{4}{|c|}{$T K=3,040+0,292^{*}(C ̧ D)$} & \\
\hline \multirow{2}{*}{ YP ve TK } & $\mathbf{R}$ & $\mathbf{R}^{2}$ & Tah.S.H. & $\mathbf{F}$ & $\mathbf{P}$ \\
\hline & 0,219 & 0,048 & 0,29088 & 10,528 & 0,001 \\
\hline \multirow{2}{*}{ Sabit } & $\beta$ & S.H. & Beta & $t$ & $\mathbf{P}$ \\
\hline & 2,210 & 0,118 & & 18,686 & 0,000 \\
\hline YP & 0,106 & 0,033 & 0,219 & 3,245 & 0,001 \\
\hline
\end{tabular}

Tabloya göre çevre duyarlılığı ile tüketicinin satın alma kararı değişkeni arasındaki ilişkinin sınanması için regresyon analizinde $(\mathrm{F}=50,329 ; \mathrm{p}<0,05)$ istatistiksel olarak anlamlı bir ilişki bulunmuştur. Bağımsız değişken Çevre Duyarlılığı bağımlı değişken Tüketici Satın Alma kararı üzerinde regresyon $(\beta=0,292 \mathrm{p}<0,05)$ sonucuyla bir etkiye sahip olduğu görülmektedir. Belirlilik katsayısı $R^{2}=0,195$ olarak bulunmuş olup, tüketicinin satın alma kararındaki değişimin \%19,5'i çevre duyarlılığı tarafından açıklandığı söylenebilir. 
Yeşil pazarlama ile tüketicinin satın alma kararı değişkeni arasındaki ilişkinin sınanması için regresyon analizinde $(F=10,528 ; p<0,05)$ istatistiksel olarak anlamlı bir ilişki bulunmuştur. Bağımsız değişken Yeşil Pazarlama bağımlı değişken Tüketici Satın Alma kararı üzerinde regresyon $(\beta=0,106$ $p<0,05)$ sonucuyla bir etkiye sahip olduğu görülmektedir. Belirlilik katsayısı $\mathrm{R}^{2}=0,048$ olarak bulunmuş olup, tüketicinin satın alma kararındaki değişimin \%4,8'i yeşil pazarlama tarafından açıklandığı söylenebilir.

Tablo 11. Hipotezlerin test edilmesi

\begin{tabular}{llc}
\hline \multicolumn{1}{c}{ Hipotez } & P & Sonuç \\
\hline $\begin{array}{l}\text { H1: Çevre Duyarlılığı, Tüketicinin Satın Alma kararları üzerinde anlam- } \\
\text { lı etkisi vardır }\end{array}$ & 0,000 & Kabul \\
$\begin{array}{l}\text { H2: Yeşil Pazarlama, Tüketicinin Satın Alma kararları üzerinde anlamlı } \\
\text { etkisi vardır }\end{array}$ & 0,001 & Kabul \\
\hline
\end{tabular}

Elde ettiğimiz bu bulgular literatürdeki bazı çalışmalarla örtüşmektedir. Aslan (2007) çalışmasında katılımcı öğrencilerin çevreye zarar verici ürünleri satın almamaya özen gösterdiği, geri dönüşümü mümkün olan ürünleri kullanma eğiliminde olduklarını ileri sürmüştür. Üstünay (2008) çalışmasında çevre kirliliğine bağlı artış gösteren güvenlik endişelerinin işletmelerce önemli olduğunu iddia etmiştir. Sarı (2010) çalışmasında psikografik değişkenlerin çevresel kaygıların ve algılanan tüketici etkinliğinin bilinçli tüketici davranışlarıyla anlamlı ilişkisi olduğunu ifade etmiştir. Boztepe (2011) çalışmasında çevre bilinci, yeşil ürün, yeşil tanıtım, yeşil fiyat tüketicilerin satın alma davranışlarını olumlu yönde etkilediğini ileri sürmüştür. Kuduz (2011) çalışmasında yeşil pazarlama uygulamalarının tüketicilerin satın alma davranışlarında etkili olduğunu iddia etmiştir. Çelik (2012) çalışmasında satın alma ve tüketimde çevreye duyarlı olan davranışların demografik (cinsiyet, medeni durum ve yaş) unsurlar ile anlamlı ilişkileri olduğunu iddia etmiştir. Karaca (2013) çalışmasında katılımcıların demografik özellikleri ile çevre dostu ürün bilinci arasında anlamlı bir farklılık olduğunu, çevre duyarlılığının artmasından dolayı tüketicilerin çevre dostu ürün satın alma davranışını pozitif yönde etkilediğini ileri sürmüştür. Veziroğlu (2014) çalışmasında tüketicilerin çevresel duyarlılığı ile cinsiyet, yaş ve sahip oldukları çocuklar bakımından anlamlı farklılık olmadığını ileri sürmüştür. Biner (2014) çalışmasında yeşil satın alma davranışının çevresel duyarlılık ve tüketici etkinliği ile anlamlı doğrusal ilişki olduğunu ileri sür- 
müştür. Sönmez (2014) çalışmasında yaş, cinsiyet ve medeni durumun yeşil pazarlama faaliyetleri ile ilgili anlamlı farklılı̆̆ın bulunmadığını iddia etmiştir. Bakar (2015) çalışmasında yeşil pazarlamanın satın alma davranışlardaki etkisinin düşük olduğunu iddia etmiştir. Türkoğlu (2016) çalışmasında tüketicilerin yeşil ürünlere daha fazla ödeme yapabileceklerini ileri sürmüştür. Sert (2017) çalışmasında çevresel duyarlılık ile yeşil pazarlamaya yönelik satın alma davranışları arasında anlamlı ilişki olduğunu ifade etmiştir. Çınar (2017) çalışmasında çevre bilinci olan tüketici davranışının yeşil satın almayla anlamlı ve güçlü ilişki olduğunu iddia etmiştir. Dinç (2018) çalışmasında medeni durum ve cinsiyetin yeşil satın alma davranışlarında farklılık oluşturmadığın ifade etmiştir. Dinar (2018) çalışmasında yeşil reklamlar ve çevre bilincinin satın alma davranışları arasında pozitif yönlü ilişki bulunduğunu ileri sürmüştür. Öndoğan (2018) çalışmasında yeşil pazarlama kapsamında doğaya duyarlı tasarımlar ve ürünlerin, organik ürünlerin ve kalite belgeli ürünlerin üretilmesine ve dağıtılmasının hem işletmeler hem de müşteriler için faydalı olabileceğini ifade etmiştir. Gemlik vd. (2019) çalışmasında hastane yöneticilerinin yeşil bir hastanede çalışma farkındalığının yeterli olmadığı, yeşil hastane konusundaki eğitimlerin bütünleştirici olması gerekliliğini ifade etmiştir.

\section{Sonuç ve Öneriler}

Yapılan bu çalışmanın amacı Çevre duyarlılığı, yeşil pazarlama ve tüketici satın alma kararı arasındaki ilişkinin belirlenmesidir. Bu amaçla Kütahya ili SERA alışveriş merkezinde 210 tüketiciye gönüllülük esasına göre ulaşılmıştır. Günümüz dünyasında değişen ekonomik şartlara pazarlama uygulamalarının katkısı büyüktür. Pazarlama, işletme amaçlarının gerçekleştirilmesi için ihtiyaçların karşılanması, ürün/hizmet fikirlerinin gerçekleştirilmesi, fiyatlandırılması, tutundurulması ve dağıtılmasını kapsamaktadır. Bu kapsamda tüketici istek ve beklentilerinin karşılanması pazarlama yoluyla olmaktadır. Günümüzdeki pazarlama anlayışında tüketici istek ve beklentilerinin ötesinde bazı sosyal görevleri de kapsamaktadır. Bu görevlerin bir kısmı çevreyi korumayı hedeflemiş yeşil pazarlama ile ilgilidir. Yeşil pazarlama faaliyetleri tüm pazarlama faaliyetlerini etkileyerek yeşil üretim, yeşil satış, pazar araştırmaları, pazarlama kararları, teknolojileri, ambalaj, etiketlenme, tüketim ve atıl- 
masını kapsamaktadır. Yeşil pazarlama, pazarlama ve ekolojinin tüketicilerin sergilediği çevreci tutum ve davranışlar altında birleştirmektir. Yeşil pazarlama uygulamaları işletme yöneticilerine çevre konusunda bazı görev ve sorumluluklar yüklemektedir.

Elde ettiğimiz bulgularla çevre duyarlılığ ile tüketici satın alma kararı arasında pozitif yönlü anlamlı ilişkileri tespit edilmiştir. Ayrıca, yeşil pazarlama ile tüketici satın alma kararı arasında pozitif yönlü anlamlı ilişkileri tespit edilmiştir. Demografik değişkenlerden cinsiyet ile çevre duyarlılığı, yeşil pazarlama ve tüketici satın alma kararı arasında anlamlı farklılığa rastlanmamıştır. Demografik değişkenlerden medeni durum ile çevre duyarlılığı ve tüketici satın alma kararı arasında anlamlı farklılık tespit edilmişken yeşil pazarlama ile arasında anlamlı farklılı̆̆a rastlanmamıştır. Ayrıca tüketicilerin çevre dostu ürünleri satın almak istediklerinde $\% 21,15$ daha fazla ödeme yapacakları tespit edilmiştir.

Elde edilen bulgular neticesinde üreticiler, tüketiciler ve üretim ve tüketimdeki diğer paydaşlara yönelik şu önerilerde bulunulabilir;

- Tüketiciler market raflarından alacakları ürünlerin içeriklerini doğa dostu olup olmadığını kontrol etmesi,

- Tüketicilerin ozon tabakasına zarar veren gazları ihtiva eden sprey, deodorant vb. ürünleri alırken fayda-maliyet analizi yapması,

- Ülkelerin gelişmesi için enerji ihtiyacının gerekliliğinin bilincine varıp nükleer enerjiye karşı yürütülen olumsuz propagandalara alet olunmamas1,

- Tüketicilerin satın alacakları ürün ambalajlarının doğa dostu olup olmadığının kontrol edilmesi,

- Tüketicilerin çevre dostu ürünleri çevre dostu olmayan ürünlerle kıyaslarken sadece fiyat temelli kıyaslama yapmaması,

- Tüketicilerin yeteri kadar ambalajlı ürünleri tercih etmesi,

- Yerel yönetimler tarafından evsel atıkların (plastik, cam, kağıt, ve pil/elektronik cihaz gibi dünyamıza zarar veren atıkları) ayrıştırılarak atılmasının sağlanması,

- Doğal kaynaklarımızdan ormanların tükenebileceğini düşünerek faturaların elektronik postayla (e-posta) gönderilmesinin sağlanması,

- Satın alınan ürünün çevreye zarar vererek üretildiğinin öğrenildiğinde kullanımından vazgeçilmesi, 
- Üretici ve tüketicilerin geri dönüşümlü malzemeden yapılmış ürünlerin üretimi ve kullanımını tercih etmesini sağlayacak teşvikler sağlanmass,

- Alışveriş yaparken alınan malzemelerin taşınmasında file, kese kağıdı, pamuklu torbalar gibi malzemelerin kullanılması önerilebilir. 
EXTENDED ABSTRACT

\title{
The Impact of Green Marketing Activities on Consumers
}

\author{
Dursun Boz-Cengiz Duran-Sadık Başköy \\ Dumlupinar University
}

Human beings have lived with nature and living things from the day they existed. Most of the time he tried to dominate this nature he lived in. He tried to make this rule with the tools and equipments he produced using his mind. With the globalization and technological developments, the need for socialization has been met with consumption. This consumption demand was met by producers. Producers have done damage to the natural environment and natural resources have declined in meeting this crazy demand. Since this situation has increased the concerns of some consumers, green marketing elements that are friendly to nature have come up. The basis of these elements is that nature is an environment that we can entrust to our grandchildren, not inherited from our ancestors. The movement initiated by consumers with this concern is integrated into the green marketing framework. Today's businesses should be able to demonstrate their social responsibility approaches by implementing environmentally friendly strategies and meet the demands and expectations of consumers who long for a green world.

Recyclable products gain importance in today's consumer preferences. This importance combines green marketing with social marketing, social responsibility and sustainability. With green marketing to production and consumption is done to protect the scarce natural resources and to promote environmentally friendly products (Uydaci, 1999, p.84). In modern marketing, consumers are generally known to have high environmental awareness and awareness. For this reason, most businesses have focused on green marketing to gain a competitive advantage that will surpass their competitors. In this context, green marketing can be considered as the main trend of the modern business world (Ku et al., 2012, p.41). Peattie (2001) examines green marketing in three stages; ecological marketing between 1960-1980, environmental marketing between 1980-2000 and sus- 
tainable marketing after 2000 (Peattie, 2001, p.129). Green marketing, which is the second phase of green marketing, is the type of marketing that has gained importance in the masses in the society with the technological developments and communication technology developments that emerged in the late 1980s and the media phenomenon and the environmental phenomena that keep the events on the agenda (Sert, 2017, p.36). On the other hand, sustainable marketing is the practice that encompasses the future generations with the use of clean and beneficial technology and environmental sensitivity of the enterprises, and the realization of business activities including other elements of the enterprise (Koçarslan, 2015: 94). Efficient use of scarce resources In the production of products and services that are least harmful to the natural environment, businesses have started to act sensitive. On the basis of this behavior, consumers give importance to environmentally friendly products and services. Businesses have to pay attention to these expectations of both society and environmentally friendly consumers (Koçarslan, 2015, p.98).

Every individual involved in the consumption process is called a consumer. In essence, consumers are individuals who buy their personal needs to solve their familial needs (Jisana, 2014, p.34). Consumer behavior is the decision that people make about how to use consumption-related resources such as time and income. In the economic sense, indirect satisfaction with consumption of products and services is called benefit. Green consumers are consumers who influence the environment through their buying behavior. It includes the research on information about the producers, production activities and applications of the products purchased by green consumers with socially responsible consumption decisions, the raw materials used, and the environmental effects of the products during and after disposal (Karaca, 2013). With this content, consumers are influenced by factors such as age and generation, gender, personality, perception, learning, beliefs and attitudes, economic structure and nature, income level, family, culture, status and lifestyle. It is the responsibility of marketers to engage in informational promotional activities related to products / services. These activities can be summarized as the stages of the purchasing process with the following headings (Mucuk, 2001, p.89); the emergence of the need, determining alternatives, choosing solution options, purchasing, behavior after purchase. 
Due to the scarcity of natural resources, consumers have started to be sensitive to high levels of public environmental awareness. This sensitivity has aroused green marketing practices with consumers buying ecofriendly green products. The aim of this study is to determine the relationship between environmental sensitivity of consumers, green marketing and consumer purchasing decision. For this purpose 210 consumers were voluntarily reached at the SERA shopping center in Kütahya province. Positive correlation was found between environmental sensitivity and consumer purchasing decision. In addition, positive directional significant relationships between green marketing and consumer purchasing decision were determined. There was no significant difference between gender and environmental awareness among demographic variables, green marketing and consumer purchase decisions. While there was a significant difference between demographic variables and marital status, environmental sensitivity and consumer purchasing decision, no significant difference was found between green marketing. It was also found that consumers would pay $21.15 \%$ more when they wanted to buy eco-friendly products.

\section{Kaynakça / References}

Akdeniz Ar, A. (2011). Yeşil pazarlama: Tekstil sektöründen örneklerle. İstanbul: Beta Basım Yayın.

Akgül A. ve Çevik O. (2005). İstatistiksel Analiz teknikleri-spss'te işletme yönetimi uygulamaları. Ankara: Emek Ofset Ltd.Şti.

Altunışık, R., Özdemir, Ş. ve Torlak, Ö. (2006). Modern pazarlama. 4. Basım, İstanbul: Değişim Yayınları.

Arslanoğlu, A. (2019). İçsel pazarlamanın hasta güvenliği kültürüne etkisi. Ankara: Iksad Publications.

Aslan, F. (2007). Yeşil pazarlama faaliyetleri çerçevesinde kafkas üniversitesi öğrencilerinin çeoreye duyarl ürünleri kullanma eğilimlerini belirlemeye yönelik bir araştırma. Yayımlanmamış Yüksek Lisans Tezi, Kafkas Üniversitesi, SBE., Kars.

Bakar, B. (2015). Yeşil satın alma davranışını etkileyen faktörler: mersin ili pve kapı pencere ve granit malzemeleri üzerine bir uygulama, yayınlanmamış yüksek lisans tezi, Çağ Üniversitesi, SBE., Tarsus.

Başaran, İ.E. (1991). Eğgitim psikolojisi. Ankara: Kadıŏlu Matbaası.

Bilge, F. A. ve Göksu, N. (2010). Tüketici davranışları. Ankara: Gazi Kitapevi. 
Biner, N. (2014). Tüketicilerin yeşil ürün satın alma davranışlarının incelenmesi. Yayınlanmamış Yüksek Lisans Tezi, Trakya Üniversitesi, SBE., Edirne.

Blythe, J. (2013). Consumer behaviour, 2nd ed. Sage. HF5415.32 B59 2013. Los Angeles.

Boztepe, A. (2011). Green marketing and its impact on consumer buying behavior, Unpublished Master's Thesis, Fatih University, İstanbul.

Büyüköztürk, Ş. (2007). Sosyal bilimler için veri analizi el kitabı, 7. Baskı, Ankara: Pegem Akademi Yayıncılık.

Ceritoğlu, B. (2011). kurumsal sosyal sorumluluk ve işletmelerin çevre bilinci eksenindeki uygulamalarının tüketici satın alma davranışı ve kurum algısı imajına etkisi. İstanbul: Yalın Yayıncılık.

Çağlayan, E. ve Güriş, S. (2005). Ekonometri temel kavramlar. İkinci Baskı, İstanbul: Der Yayınları, 12.

Çınar, S. (2017). Tüketicilerin yeşil ürün satın alma eğilimlerinin belirlenmesi dumlupınar üniversitesinde bir araştırma, Yayınlanmamış Yüksek Lisans tezi, Dumlupınar Üniversitesi, SBE., Kütahya.

Çelik, A.A. (2012). Tüketicilerin değer yapılarının, demografik ve psikografik özelliklerinin çevreye duyarl tüketim davranışı üzerindeki etkilerinin incelenmesi. Yayınlanmamış Doktora tezi, Dokuz Eylül Üniversitesi, SBE., İzmir.

Dinar, N. (2018). Yeşil reklamların ve çevre bilincinin yeşil ürün satın alma niyeti üzerine etkisi. Yayınlanmamış Yüksek Lisans tezi, Marmara Üniversitesi, SBE., İstanbul.

Dinç, Y. (2018). Yeşil pazarlama ve tüketicilerin yeşil ürünlere yönelik tutumlarına ilişkin değerlendirme. Yayınlanmamış Yüksek Lisans Tezi, Beykent Üniversitesi, SBE. İstanbul.

Djaadi, N. (2016). Yeşil pazarlama uygulamalarının tüketici satın alma davranışları üzerine etkisi: türkiye ve cezayir örneği. Yayınlanmamış Yüksek Lisans Tezi, Trakya Üniversitesi, SBE., Edirne.

Gemlik, N., Arslanoğlu, A., Gün, M. ve Aslan, Ü. (2019). Tastane yöneticilerinin yeşil hastane farkındalığı üzerine nitel bir araştırma, Uluslararası Sosyal ve Beşeri Bilimler Araştırma Dergisi, 6(40), 2135-2144.

Glowa, T. (2001). Understanding how consumers make complex choices, Unpublished White Paper.

Gürbüz, S. ve Şahin, F. (2014). Sosyal bilimlerde araştırma yöntemleri, 1.Baskı, Seçkin Yayıncılık, Ankara. 
Hamşıŏlu, B. (2013). Fastfood ürünleri satın alma tüketicilerin yaşam tarzlarını belirlemeye yönelik bir uygulama. Uluslararası Íktisadi ve İdari İncelemeler Dergisi, 6(11), 20.

İslamoğlu, A.H. (2003). Tüketici davranışları. İstanbul: Beta Basım Yayım Dağıtım. ISBN 975-29-5312-3.

Jisana, T.K. (2014). Consumer behaviour models: an overview. Sai Om Journal of Commerce \& Management, 1(5), 34-43.

Kalaycı, Ş. (2010). spss uygulamalı çok değişkenli istatistik teknikleri, 5.Baskı., Ankara: Asil Yayın Dağıtım.

Karaca, C. (2012). Ekonomik kalkınma ve çevre kirliliği ilişkisi: gelişmekte olan ülkeler üzerine ampirik bir analiz. Çukurova Üniversitesi, SBE.Dergisi, 21(3), 139-156.

Karaca, S. (2013). Tüketicilerin yeşil ürünlere ilişkin tutumlarının incelenmesine yönelik bir araştırma /a research on investatigation of consumers' attitudes on green products. Ege Akademik Bakış, 13(1), 99.

Karalar, R. ve Kiracı, H. (2011). Çevresel sorunlara karşı bir çözüm önerisi olarak sürdürülebilir tüketim düşüncesi Dumlupınar Üniversitesi SBE Dergisi, 30.

Kocabaş, F. ve Elden, M. (2001). reklamcilık kavramlar, kararlar, kurumlar, İstanbul: İletişim Yayınları,

Koçarslan, H. (2015). İşletmelerin sosyal sorumluluk bilincinde çevre duyarlılğ̆ııı yeşil pazarlama üzerine etkileri, Doctoral dissertation, Doktora Tezi. Kilis 7 Aralık Üniversitesi Sosyal Bilimler Enstitüsü. Kilis.

Kotler, P., Wong, V., Saunder, J. ve Armstrong, G. (2005). Principles of marketing, (Fourth Europan Edition). New Jersey: Prentice Hall.

$\mathrm{Ku}, \mathrm{H} . \mathrm{H} ., \mathrm{Kuo}, \mathrm{C} . \mathrm{C}$. , ve Kuo, T.W. (2012). The effect of scarcity on the purchase intentions of prevention and promotion motivated consumers. Psychology and Marketing, 29(8), 541-548.doi:10.1002/mar.20541.

Kuduz, N. (2011). Yeşil pazarlama faaliyetlerinin tüketicilerin satın alma davranışlarına etkilerinin belirlenmesine yönelik bir araştırma, Yayınlanmış Yüksek Lisans tezi, Selçuk Üniversitesi Sosyal Bilimler Enstitüsü, Konya.

Kuduz, N. ve Zerenler, M. (2013). Yeşil pazarlama, Ankara: Nobel Yayınları.

Mucuk, İ. (2001). Pazarlama ilkeleri, İstanbul: Türkmen Kitabevi.

Nakip, M. (2006). Pazarlama araştırmaları teknikler ve uygulamalar, Ankara: Seçkin Yayınevi.

Öndoğan, E. N. (2018). Hazır giyim sektörü ve yeşil pazarlama. Çukurova Üniversitesi Sosyal Bilimler Enstitüsü Dergisi, 27(2), 97-110. 
Peattie, K. (2001). Towards sustainability: the third age of green marketing. The Marketing Rewiew. 2, 129-146.

Sarı, T.B. (2010). Green marketıng: attıtudes of consumers towards green products, Unpublished Master's Thesis, The Institute Of Social Sciences Marketing Graduate Programme Bahçeşehir University, İstanbul.

Schewe, C. D. ve Meredith, G. (2004). Segmenting global markets by generational cohorts: determining motivations by age, Journal of Consumer Behavior, 4(1), 51-63.

Sert, A. (2017). Yeşil pazarlama ve tüketicilerin satın alma davranışları: üniversite öğrencilerine yönelik bir araştırma, Yayınlanmamış Yüksek Lisans tezi, Nişantaşı Üniversitesi, SBE., İstanbul.

Smith, P.R. (1994). Marketing comunication an integrated approache, London: Kogan Page Limited.

Sönmez, Y. (2014). Tüketicilerin yeşil pazarlama uygulamalarıla ilgili tutum ve davranışları: ahi evran üniversitesi örneği, Yayınlanmamış Yüksek Lisans Tezi, Nevşehir Hacı Bektaş Veli Üniversitesi, SBE., Nevşehir.

Toygar, F. (2014). Yeşil (çevreci) pazarlama faaliyetleri ve tüketici karar süreci üzerindeki etkisi, örnek olay incelemesi, Yayınlanmamış Yüksek Lisans Tezi, Gediz Üniversitesi, Sosyal Bilimler Enstitüsü, İzmir.

Türkoğlu, A. (2016). Examinating the effects of green marketing on the purchasing behaviours of consumers in sociodemographic aspects, Unpublished Master's Thesis, The Institute Of Social Sciences Master Of Business Administration Bahçeşehir University, İstanbul.

Tüylü, V. (1995). Üniversite Öğrencilerinin giyim eşyası satın almasında.yerliithal mali tercihlerinin belirlenmesi Pazarlama Dünyası, 51, 32 -38.

Uydacı, M. (1999). İş ahlakı açısından çevresellik ve yeşil pazarlama anlayışı. Doktora Tezi, Marmara Üniversitesi Sosyal Bilimler Enstitüsü.

Uydacı, M. (2011). Yeşil pazarlama. 2.Baskı, İstanbul: Türkmen Kitabevi.

Üstünay, M. (2008). İşletmelerin sosyal sorumluluklar çerçevesinde yeşil pazarlama uygulamaları ve kimya sektörüne yönelik bir inceleme, Yayınlanmamış Yüksek Lisans tezi, Trakya Üniversitesi, SBE., Edirne.

Veziroğlu, P. (2014). Gıda ürünleri pazarlamasında yeşil pazarlama kavramı ve tüketici yaklaşımı: adana ili örne ği, Yayınlanmamış Yüksek Lisans tezi, Çukurova Üniversitesi, SBE., Adana.

Wood, W. ve Hayes, T. (2012). Social influence on consumer decisions: motives, modes, and consequences. Journal of Consumer Psychology, 22, 324-328. 


\section{Kaynakça Bilgisi / Citation Information}

Boz, D., Duran, C. ve Başköy, S. (2020). Yeşil pazarlama faaliyetlerinin tüketiciler üzerindeki etkileri. OPUS-Uluslararası Toplum Araştırmalarn Dergisi, 15(22), 1346-1372. DOI: 10.26466/opus.615467 